\title{
Organizacja pracy więźniów w Królestwie Polskim w latach 1815-1867
}

Obowiązek pracy więźniów jako dodatkowa dolegliwość kary pozbawienia wolności sięga jeszcze czasów przedrozbiorowych ${ }^{1}$. Po raz pierwszy obowiązek ten pojawił się w XVI w. wraz z powstaniem domów poprawy. W Europie prekursorem tworzenia takich domów była Anglia, choć prawdziwy rozkwit tej instytucji zawdzięczamy Niderlandom. Pojawienie się tego rodzaju ośrodków wymusiła rozwijająca się gospodarka XVI w., borykająca się z ciągłym deficytem rąk do pracy. Warunkiem jej dalszego rozwoju było poszukiwanie stałego dopływu siły roboczej. Rozwiązania szukano w pracy przymusowej, którą miała wykonywać biedota miejska, kierowana do domów poprawy zwykle za pospolite przestępstwa. Idea tworzenia takich ośrodków dotarła także do Rzeczypospolitej, w której pierwszy taki zakład powstał w Gdańsku w 1630 r., a następnie w Toruniu, Elblągu, Krakowie, a w latach trzydziestych XVIII w. także w Warszawie².

W XIX w. obowiązek pracy więźniów jako element kary pozbawienia wolności zwiększający jej znaczenie i dolegliwość został unormowany ustawowo w wielu europejskich kodeksach karnych ${ }^{3}$. Taką też koncepcję zakładało ustawodawstwo karne obowiązujące w Królestwie Polskim, tj. Kodeks Karzący (obowiązujący od 1818 r.) oraz Kodeks Kar Głównych i Poprawczych (obowiązujący od 1848 r.).

Analizie poddane zostały regulacje zawarte zarówno w ustawach karnych, jak i przepisach administracyjnych wydawanych przez centralne organy administracji

\footnotetext{
1 J. Rafacz, Więzienie marszałkowskie w latach 1767-1795, Lwów 1932 r., s. 27.

2 T. Adamczyk, O karze pozbawienia wolności w orzecznictwie krakowskiego sadu grodzkiego w XVIII wieku uwag kilka, [w:] Z Dziejów Prawa t. 4, Katowice 2011, s. 61.

3 J. Morelowski, O zatrudnianiu więźniów uprawą roli, Kraków 1884, s. 21.
} 
rządowej Królestwa Polskiego, w tym przede wszystkim przez Komisję Rządową Spraw Wewnętrznych i Duchownych. Moment likwidacji komisji stanowi datę graniczną niniejszych rozważań.

Analiza dostępnego materiału archiwalnego miała na celu zbadanie praktycznego funkcjonowania i wykonywania decyzji podejmowanych przez komisje rządowe. Niestety materiał ten nie jest on zbyt obszerny. Można wskazać jedynie kilka protokołów z posiedzeń Rady Administracyjnej, pięć jednostek zachowanych w aktach Rządu Gubernialnego Radomskiego ${ }^{5}$, dwie jednostki z zespołu Więzienia Piotrkowskiego ${ }^{6}$ oraz jedną z akt Komisji Województwa Mazowieckiego ${ }^{7}$.

\section{ROLA PRACY WIĘŹNIÓW}

W Królestwie Polskim praca osadzonych miała przede wszystkim charakter fiskalny, którego celem było zapracowanie przez więźnia, choćby częściowo, na jego utrzymanie ${ }^{8}$.

Rosnące koszty utrzymania więźniów spowodowały, iż kwestia zwiększenia dochodów z pracy osadzonych stała się przedmiotem rozważań Rady Administracyjnej. Podczas posiedzenia w dniu 4 stycznia 1825 r. nakazała ona Komisji Rządowej Sprawiedliwości, Komisji Rządowej Spraw Wewnętrznych, a także Komisji Przychodów i Skarbu (wspólnie z Izbą Obrachunkową) wydanie stosownych przepisów administracyjnych, które pozwoliłyby na czerpanie zysków z pracy więźniów ${ }^{9}$. Nie wiadomo jednak, czy takie przepisy rzeczywiście zostały wydane.

W 1828 r. Rada Administracyjna ponownie zajęła się kwestią dochodów z pracy więźniów zwiększając dzienną stawkę wynagrodzenia z 10 do 20 groszy (jak argumentowano, dotychczasowa kwota nie wystarczała nawet na dzienne utrzymanie osadzonego). Dopuszczano jednak możliwość obniżenia tego wynagrodzenia, gdzie by przy sposobności wynajęcia za cenę podobna do robót prywatnych człowieka wolnego chętniej najmowanego zapewnienie konkurencji

${ }^{4}$ Protokół posiedzenia Rady Administracyjnej z 13 VI 1818 r., 18 II 1823 r., 4 I 1825 r., 24 III $1829 \mathrm{r}$.

5 Archiwum Państwowe w Radomiu (dalej: AP w Radomiu), zespół nr 44 Rząd Gubernialny Radomski, sygn. 10688, 10689, 10691, 10692, 10693.

${ }^{6}$ Archiwum Państwowe w Łodzi (dalej: AP w Łodzi), zespół nr 73 Więzienie Piotrkowskie, sygn. $121,130$.

${ }^{7}$ Archiwum Główne Akt Dawnych (dalej: AGAD), Komisja Województwa Mazowieckiego, sygn. 10040.

${ }^{8}$ M. Senkowska, Kara więzienia w Królestwie Polskim w pierwszej połowie XIX wieku, Wroclaw 1961, s. 28-29, s. 132.

9 AGAD, Protokół posiedzenia Rady Administracyjnej z 4 I 1825 r. 
do użycia więźni i zaradzenia przez to ich bezczynności zniżenia takowego wymagaty ${ }^{10}$.

Funkcjom fiskalnym miała też służyć organizacja po 1832 r. fabryk i warsztatów więziennych. Podstawowym założeniem była produkcja przez te zakłady przedmiotów niezbędnych do funkcjonowania więzień i innych zakładów publicznych. W art. 2 postanowienia Rady Administracyjnej z 29 lipca/10 sierpnia 1832 r. czytamy: $w$ wyborze robót fabrycznych dla więźniów dane będzie pierwszeństwo, które moga dostarczać przedmiotów codziennej potrzeby dla instytutów publicznych dobroczynnych i karnych ${ }^{11}$.

Podobnie Komisja Rządowa Spraw Wewnętrznych, Duchownych i Oświecenia Publicznego w instrukcji z 30 lipca 1833 r. stanowiła, iż fabryki te miały dostarczyć przez zaopatrzyć więzienia, a następnie szpitale $w$ wyroby wetniane, lniane i konopne do codziennego ich użycia ${ }^{12}$.

$\mathrm{Z}$ biegiem czasu praca skazanych przestaje mieć tylko charakter fiskalny, pojawia się element wychowawczy.

Narodziny europejskiej literatury humanitarnej w początku XVIII w., jak dzieła Monteskiusza, Beccarii i Woltera dały początek racjonalistycznemu i humanitarnemu spojrzeniu na rolę kary za popełnione przestępstwo ${ }^{13}$. Tak też na przełomie XVIII i XIX w. zaczęto odchodzić od kar zbyt okrutnych, kary śmierci i kar cielesnych na rzecz kary pozbawienia wolności, która staje się sankcją podstawową $\mathrm{w}$ wielu europejskich kodeksach karnych. W tym samym czasie rodzą się praktyczne koncepcje penitencjarne, w świetle których więzienie przestaje być traktowane jako środek unieszkodliwienia i wyeliminowania sprawcy ze społeczeństwa, ale staje się miejscem wychowawczego oddziaływania na przestępcę. Powrót skazańca na drogę odnowy moralnej miał się odbywać przez rozmaite działania, jak np. wpajanie więźniom zasad religijnych, moralnych, nauka czytania i pisania, a także poprzez pracę ${ }^{14}$.

Jak instrument pracy jako element systemu wychowawczego był postrzegany w wybranych koncepcjach europejskich reformatorów penitencjarnych przełomu XVIII i XIX w. możemy prześledzić poniżej.

Jednym z pierwszych, a zarazem najważniejszych penitencjarystów końca XVIII w., był angielski filozof John Howard. W swoim dziele pt. Stan więzień

\footnotetext{
10 AGAD, Protokół posiedzenia Rady Administracyjnej z 24 III 1829 r.

${ }^{11}$ Zbiór Przepisów Administracyjnych Królestwa Polskiego (dalej: ZPA), cz. VI $O$ aresztach $i$ więzieniach, t. III, 1868, s. 295-297.

${ }_{12}$ ZPA, cz.VI, t. III, s. 331.

${ }_{13}$ S. Salmonowicz, Prawo karne oświeconego absolutyzmu. Z dziejów kodyfikacji karnych przełomu XVIII/XIX w., Toruń 1966, s. 25-26.

${ }^{14}$ M. Senkowska, Kara więzienia w Królestwie Polskim w pierwszej połowie XIX wieku, s. 13-14.
} 
pisze o konieczności zaprowadzenia w więzieniach tzw. pracy pożytecznej: $n a$ uczcie ich pracować, a sprawicie, że stana się uczciwi ${ }^{15}$.

Kolejnym wybitnym reformatorem więziennictwa tego okresu był angielski prawnik i filozof Jeremiasz Bentham. Uważał, że celem kary, a jednocześnie jej usprawiedliwieniem, jest prewencja ogólna, polegająca na tym, że kara wymierzona przestępcy działa odstraszająco na innych. Kładł jednak nacisk również na prewencję szczególną, mającą zapobiec popełnieniu przez skazańca czynu zabronionego w przyszłości, także prowadzić do jego poprawy moralnej ${ }^{16}$. W tym aspekcie praca była niewątpliwie czynnikiem istotnym. Jeremiasz Bentham był jednak przeciwnikiem robót przymusowych. Uważał, iż praca wymaga dużego wysiłku i może być wykonywana tylko przez ludzi wolnych, gdyż perspektywa zapłaty bardziej motywuje niż przymus i strach. Sprzeciwiał się także robotom publicznym skazanych jako okrywającym ich hańbą i uniemożliwiającym poprawę. Postulował, aby tak organizować zatrudnianie przestępców, by nie budziło to w nich odrazy, lecz było pocieszeniem i przyjemnością.

Na ziemiach polskich pierwsze tendencje położenia w systemie kar nacisku na karę pozbawienia wolności pojawiły się już w czasach stanisławowskich, wtedy też pojawiają się pierwsze teorie penitencjarne na temat warunków wykonywania i celów kary więzienia. W tym miejscu warto przywołać postać J. Szymanowskiego, który był jednym ze współautorów projektu kodeksu Andrzeja Zamoyskiego, kierownikiem resortu sprawiedliwości w rządzie Kościuszki ${ }^{17}$. W swoim dziele pt. Myśl do prospektu prawa kryminalnego podkreślał funkcję poprawczą i wychowawczą kary więzienia. Sens pracy przymusowej widział w przypadku cięższych przestępstw. Praca ta mogła odbywać się wewnątrz lub zewnątrz więzienia, np. w kopalniach, fabrykach, przy robotach publicznych. Według Szymanowskiego praca miała być odpłatna, ale część lub całość zarobku należało przeznaczać na powrócenie straty wyniklej ze zbrodni, czyli miała być przekazywana pokrzywdzonemu jako rekompensata wyrządzonych krzywd ${ }^{18}$. Szymanowski rozumiał pracę więźniów bardziej jako element sankcji i odpłaty za dokonaną zbrodnię niż instrument resocjalizacyjny.

Zasadniczy rozwój przedsięwzięć penitencjarnych w zakresie warunków wykonywania kary pozbawienia wolności datuje się przede wszystkim na okres Księstwa Warszawskiego i Królestwa Polskiego. Wtedy też rozwija się działalność publikacyjna takich wybitnych penitencjarystów, jak np. J. U. Niemcewicza,

15 Z. Bugajski, Więziennictwo. cz. 1. Zarys nauki o karze, Rawicz 1924, s. 49; L. Rabinowicz, Podstawy nauki o więziennictwie, Warszawa 1933, s. 30-32.

${ }^{16}$ T. Tulejski, Osiemnastowieczna koncepcja reformy więziennictwa Jeremyego Benthama, „Przegląd Więziennictwa”, nr 49, Warszawa 2005, s. 177.

${ }_{17}$ M. Czerwiec, Więzienioznawstwo. Zarys rozwoju więziennictwa, Warszawa 1958, s. 48.

${ }^{18}$ Ibidem, s. 49. 
K. Potockiego, A. Korzuchowskiego, F. Skarbka, J. Hallera, czy M. Nakwaskiego. Autorzy ci poruszali w swoich pracach wszystkie kluczowe zagadnienia praktyki penitencjarnej, w tym także kwestię pracy więźniów ${ }^{19}$.

Wszyscy oni uważali, że praca jest elementem służącym poprawie moralnej przestępcy.

I tak J.U. Niemcewicz pisał: przez zamknięcie więc, przez skazanie na ciężka prace, pierwszy i prawny zamiar karania uskutecznionym być powinien ${ }^{20}$. Więźniowie w ciszy i skupieniu mieli wykonywać w fabrykach więziennych obowiązkową pracę, która jednocześnie służyła nauce określonego rzemiosła ${ }^{21}$. Niemcewicz zwracał uwagę na korzyści płynące z zaszczepienia u osadzonych nawyku pracy, a także zdobycia przez nich konkretnego zawodu, co miało dać im podstawę egzystencji po odbyciu kary i tym samym zapobiec powrotowi do przestępstwa. Występował natomiast jako przeciwnik robót publicznych. Twierdził, iż są one nazbyt hańbiące i nie prowadzą do poprawy moralnej: wychodzi w kajdanach pracować na ulicach, tam rzadka pilność, częsta do ucieczki sposobność, przez napastowanie przechodzacych, zjednywana jatomużna, wraz $w$ pierwszym sklepiku, nieraz wspólnie ze straża bywa przepitą ${ }^{22}$. Co istotne, z jego poglądów na temat zatrudniania więźniów wyłania się postulat samowystarczalności zakładów karnych. Niemcewicz nawołuje, aby w miarę możliwości praca więźniów pokrywała koszty ich utrzymania.

I. Potocki określał pracę jako największe dobro w życiu ludzkim, jako matkę cnót $i$ bogactw. Ten oświeceniowy etos pracowitości rysuje się u niego znacznie silniej niż u Niemcewicza ${ }^{23}$. Potocki uważał, że praca stanowi ulgę w odbywaniu kary pozbawienia wolności, a nie jej zaostrzenie. Miała przygotować przestępcę do prawego życia na wolności, ale także zapewnić mu środki utrzymania (zasiłek) w pierwszym okresie po opuszczeniu zakładu penitencjarnego. Dlatego też postulował Potocki zakładanie w więzieniach warsztatów, w których osadzeni mogliby pobierać naukę rzemiosła ${ }^{24}$. Nauczycielami, podobnie zresztą jak u Niemcewicza, mieli być inni więźniowie, a gdyby wśród więźniów nie znajdowali się rzemieślnicy o stosownych kwalifikacjach, rząd powinien zatrudnić odpowiednich nauczycieli. W odróżnieniu od Niemcewicza Potocki nie był przeciwnikiem robót

${ }^{19}$ S. Walczak, Narodziny i rozwój koncepcji wykonywania kary pozbawienia wolności. [w:] Księga Jubileuszowa więziennictwa polskiego 1918-1988, Warszawa 1990, s. 40.

20 J.U. Niemcewicz, O więzieniach publicznych, czyli Domach Pokuty rzecz krótka, Warszawa 1818, s. 44.

${ }^{21}$ Ibidem, s. 28.

22 Ibidem, s. 56.

${ }^{23}$ M. Senkowska, Kara więzienia..., s. 28-30.

${ }^{24}$ M. Senkowska, Projekt Ksawerego Potockiego ulepszenia administracji stanu więzień publicznych w Królestwie Polskim, „Przegląd Więziennictwa”, nr 1, 1960, s. 128. 
publicznych, jednak zaznaczał, iż powinni je wykonywać sprawcy najcięższych przestępstw, nie rokujący nadziei na poprawę ${ }^{25}$.

Podobnie F. Skarbek doceniał zbawienny wpływ pracy osadzonych ${ }^{26}$. Wyraźnie sprzeciwiał się jednak (podobnie jak Niemcewicz) robotom publicznym; w jego ocenie miały one charakter hańbiący, naruszający godność osadzonego ${ }^{27}$.

W podobnym tonie, co Skarbek wypowiadał się A. Korzuchowski, który doceniał pozytywny wpływ pracy na drodze odnowy moralnej przestępcy, ale sprzeciwiał się kategorycznie pracom publicznym: używanie do zamiatania ulic, czyszczenia placów, wożenia taczkami śmieci i do tym podobnych robót nie zapewnia więźniowi uległemu nałogowi próżniactwa na przyszłość sposobu do życia, przyzwyczaja go do żebraniny i nieochędóstwa, drażni i oburza namiętności, a wszystkich uczuć szlachetnych $z$ wolna pozbawia ${ }^{28}$. Dlatego też uważał, iż więźniowie powinni wykonywać tylko takie prace, które jednocześnie pozwolą im na zdobycie zawodu, co miało zapewnić im środki utrzymania po wyjściu na wolność.

$\mathrm{Na}$ wzmiankę zasługuje pochodzący z Krakowa J. Haller. Ten jeden z pierwszych polskich penitencjarystów był wielkim zwolennikiem domów pracy. Uważał, iż większość przestępstw bierze się z lenistwa i bezczynności. Stąd istotne znaczenie $\mathrm{w}$ walce $\mathrm{z}$ przestępczością upatrywał w wykonywaniu obowiązków pracy $\mathrm{w}$ więzieniach, co miało sprzyjać zainteresowaniu więźniów pracą i wdrażać do jej wykonywania. Haller twierdził, iż aby praca była atrakcyjna, musi być wynagradzana stosownie do jej jakości i ilości. Podobnie jak Skarbek sprzeciwiał się pracy poza murami więzienia ${ }^{29}$.

Zasadniczo jednak do lat trzydziestych XIX w. praca więźniów w praktyce penitencjarnej władz Królestwa Polskiego nie była łączona z czynnikiem mającym wpłynąć na poprawę moralną przestępców, miała ona czysto fiskalny charakter.

Podstawową formą zatrudnienia były roboty publiczne, które nie wyczerpywały potencjału siły roboczej, co powodowało, że spora część więźniów (szczególnie kobiet) pozostawała bez pracy. Stan taki nie tylko ujemnie odbijał się na karności więźniów, którzy często zupełnie bezczynnie spędzali całe dnie w dusznych i brudnych celach, ale i powodowało, że skazani nie zarabiali na siebie ${ }^{30}$.

${ }^{25} \mathrm{~K}$. Potocki, Uwagi do projektu ogólnego i szczególnego ulepszenia administracji i stanu więzień publicznych w Królestwie Polskim, Warszawa 1819, s. 17-19.

${ }^{26}$ F. Skarbek, O poprawie moralnej winowajców w więzieniach, Warszawa 1822,, s. 11.

${ }^{27}$ Ibidem, s. 19-20.

28 A. Korzuchowski, O więzieniach, Warszawa 1825, s. 159.

${ }^{29}$ M. Czerwiec, op. cit., s. 60-61.

${ }^{30}$ M. Senkowska, Kara więzienia..., s. 134. Twierdzenia M. Senkowskiej niewątpliwie potwierdza fakt, iż zasadniczo próżno szukać w archiwach dokumentujących funkcjonowanie poszczególnych więzień w Królestwie Polskim informacji o zatrudnianiu skazanych w pierwszym trzydziestoleciu XIX w. 
Dopiero reformatorska działalność Fryderyka Skarbka spowodowała, iż po raz pierwszy fakt zatrudniania osadzonych zaczęto łączyć z kwestią ich poprawy moralnej. Dlatego po 1832 r. podjęto próby zmiany całej struktury zatrudniania. Zaczęto odchodzić od robót publicznych (uważanych za pracę hańbiącą) na rzecz prac fabrycznych, które nie tylko miały przynosić określone korzyści materiale, ale także być źródłem odnowy moralnej przestępcy i elementem przygotowującym go do prawego życia po wyjściu na wolność.

I tak w postanowieniu Namiestnika z 29 lipca/10 sierpnia 1832 r. nakazującym we wszystkich większych więzieniach organizację fabryk i warsztatów (co do tej pory stanowiło rzadkość) czytamy: zważywszy konieczna potrzebę zaradzenia nieczynności, w której więźniowie, za wyrokiem $w$ więzieniach osadzeni, częstokroć czas swój przepędzaja, dla braku statego sposobu ich zatrudniania, pragną uregulować $i$ nadać dążność użyteczniejsza, zgodniejsza z poprawa moralna więźniów, robotom przez nich wykonywanym. Dalej art. 2 przywołanego aktu mówił, iż w warsztatach i fabrykach więziennych wybierać się ma takie zatrudnienia, które moga uksztatcić więźnia do rzemiost przydatnych dla niego, po wyjściu z więzienia ${ }^{31}$.

Istotnym elementem wychowawczym i mobilizującym do pracy miało być wypłacanie części wynagrodzenia bezpośrednio do rąk więźniów. Jednak było to źródłem wielu nadużyć i po wejściu w życie Kodeksu Karzącego zakazano takiej praktyki.

Jak czytamy w piśmie Komisji Rządowej Spraw Wewnętrznych i Policji z 19 grudnia 1819 r. skierowanym do komisji wojewódzkich: zważają, iż przepisy prawa Karnego Krajowego, a mianowicie art. 31. 32, 216, 217 Księgi 1-szej i 2-giej wskazuje sposób utrzymania więźni, zwyczaj zaś dotąd w administracji więzień trwających dawania więźniom użytym do robót publicznych do rąk dodatku w pieniqdzach z dozwoleniem użycia takowych wedtug ich woli, nie tylko sprzeciwia się rzeczonym przepisom prawa karnego, lecz nadto jest powodem wielu nadużý ze strony administracji więzień i staje się przeszkoda do zapewnienia potrzebnego porządku i bezpieczeństwa w więzieniach. Komisja Rzadowa Spraw Wewnętrznych i Policji dla zapobieżenia takowym, uchyla niniejszym zupetnie powyżej rzeczony zwyczaj polecając Komisji Wojewódzkiej, iżby w utrzymaniu więzień stosowała się do przepisów prawa karnego i wyroków sądowych... zarządzając, aby więźnie do robót publicznych użyci lub wewnątrz więzień użyci zadnych dodatkowych pieniędzy do rąk nie odbierali ${ }^{32}$. Zgodnie z wytycznymi komisji rządowej pieniądze te miały znajdować się w dyspozycji kasy więziennej i być przeznaczane na polepszenie wyżywienia więźniów pracujących przy

\footnotetext{
${ }^{31}$ ZPA, cz. VI, t. III, s. 297.

${ }^{32}$ AGAD, Komisja Województwa Mazowieckiego, sygn. 10040.
} 
robotach publicznych (tych, którzy odznaczali się szczególną pilnością i dobrym sprawowaniem) lub też na zapomogi dla osób wychodzących na wolność. Co ciekawe, w piśmie tym Komisja Rządowa Spraw Wewnętrznych i Policji wyraźnie wskazała, iż te środki finansowe nie mogą być przeznaczane na dostarczanie więźniom trunków, z czego można wnioskować, iż takie praktyki miały miejsce ${ }^{33}$.

Instrukcja więzienna z $1823 \mathrm{r}$. w art. 108 również wykluczała możliwość pobierania przez skazanych jakiegokolwiek wynagrodzenia za wykonane prace. Z czasem organy administracji rządowej powróciły do przekonania, że niewielka gratyfikacja będzie dodatkowym elementem wychowawczym i motywującym więźniów do rzetelnego wykonywania obowiązków. Jednak tym razem próbowano znaleźć rozwiązanie, które z jednej strony będzie dawało osadzonemu poczucie uzyskania realnej korzyści za wykonaną pracę, a z drugiej wyeliminuje wcześniejsze nadużycia.

I tak zgodnie z decyzją Rady Administracyjnej z 12/24 marca 1846 r. skazańcy za pracę w fabrykach i warsztatach więziennych mieli otrzymywać niewielką gratyfikację (maksymalnie około 1,5 rubla na rok). Każdy zatrudniony był wyposażony w książeczkę (oznaczoną imieniem i nazwiskiem oraz numerem rodowodowym, pod którym wpisany był więzień), do której co tydzień wpisywano zarobioną sumę. Miało to stanowić dodatkowy element motywacyjny: ksiażeczki te maja być ciagle przed oczami swych wtaścicieli, to jest więźniów robotników, podczas pracy przez nich wykonywanej, czyli zostawać na narzędziach w fabryce, na których pracuja, aby każdy z robotników zawsze wiedziat ile sobie zarobi ${ }^{34}$. Zgodnie z decyzją Komisji Rządowej Spraw Wewnętrznych i Duchownych z 5/17 kwietnia $1846 \mathrm{r}$. zarobiona suma miała być wypłacana dopiero z chwilą wyjścia na wolność ${ }^{35}$. Jak wynika z protokołu posiedzenia Rady Administracyjnej z 12/24 marca 1846 r., wynagrodzenie nie było własnością skazanego, stanowiło jedynie wsparcie, które miało mu pomóc rozpocząć nowe życie po odbyciu kary. Dlatego też np. w wypadku śmierci więźnia nie było ono wypłacane rodzinie, lecz powiększało tzw. fundusz na wynagrodzenia więźniów ${ }^{36}$.

${ }^{33}$ AGAD, Komisja Województwa Mazowieckiego, sygn. 10040.

34 ZPA, cz.VI, t. III, s. 441.

${ }^{35}$ ZPA, cz.VI, t. III, s. 441. Rozporządzenie Komisji Rządowej Spraw Wewnętrznych i Duchownych z 5/17 kwietnia 1846 r. stanowiło jedynie wprowadzenie w życie decyzji w tym przedmiocie podjętej w dniu 12/24 marca 1846 r. przez Radę Administracyjną (por. ZPA, cz.VI, t. III, s. 441).

${ }^{36}$ ZPA, cz.VI, t. III, s. 407. Jak czytamy w protokole posiedzenia Rady Administracyjnej z 12/24 marca 1846 r.: Rząd używając więźni do prac fabrycznych, daje gorliwszym, przy wyjściu ich z więzienia, pewna kwotę pieniężna w stosunku ich pracy, czyni to jedynie jako wsparcie dla dania uwolnionemu możności przedsięwzięcia uczciwego zarobku i stania się przez to użytecznym społeczności członkie; że zatem podobne wsparcie nie jest ich własnościa przed wyjściem z więzienia i gdyby takowe, w razie śmierci więźnia w więzieniu przechodziło do jego sukcesorów, chybiony bytby cel, w jakim Rzad takowe wyznacza. 
Podobne zasady utrzymywała instrukcja więzienna z 1859 r. Pracujący więźniowie nadal mieli książeczki, do których wpisywano zarobione sumy, wypłacane dopiero z chwilą opuszczenia zakładu karnego ${ }^{37}$. Jak poprzednio, w razie śmierci aresztanta zarobek po nim rozdzielony ma być pomiędzy innych pilnych i dobrze sprawujacych się aresztantów, w kwocie nieprzekraczajacej rs 3 na jednego ${ }^{38}$.

Jako nowe rozwiązanie przepisy z 1859 r. wprowadziły zasadę, iż należne skazanym pieniądze za pracę miały być deponowane na odpowiedni procent $\mathrm{w}$ kasach oszczędnościowych ${ }^{39}$. Co ważne, nowe przepisy stanowiły, iż wynagrodzenie nie należy się, jako pozbawionym wszelkich praw cywilnych, osobom skazanym na kary główne ${ }^{40}$. W celu zachęcenia więźniów do wydajniejszej pracy nowa instrukcja w art. 503 przewidywała, iż skazanym (nie wyłączając osób skazanych na kary główne) odznaczającym się pilnością w pracy i dobrym zachowaniem, można było dostarczać na poczet zarobionych pieniędzy dodatkowe porcje chleba i tabaki: aresztantom odznaczajacym się pilnościa $w$ robocie i przyzwoitym postępowaniem, nie wyłaczajac także i przestępców na kary główne skazanych, udzielane być maja z zarobków ich własnych $w$ fabrykach i przędzalniach, dla podtrzymania dobrych ich chęci do pracy powiększone porcje chleba i tabaki. Artykuty te będa dostarczane przez Nadzorców więzien, a koszt ich zapisywany w ksiązeczkach zarobkowych więźniów...baczyć wszakże należy, aby wydatek w tym względzie czyniony byt z jak największa oględnościa i żeby przez to ci, którzy maja prawo do otrzymania pieniędzy z swych zarobków, nie byli przy wyjściu z więzień pozbawieni potrzebnego fundusz $u^{41}$.

${ }^{37}$ Art. 498 instr. z 1859 r. - Zarobek każdego aresztanta z tej pracy; przy każdym oddaniu utkanej sztuki wyrobu lub uprzędzonego funta materyalu itp. Zapisywany być ma w ksiażeczkę z papieru...oznaczona nazwiskiem i numerem rodowodu więźnia, jaka każdy robotnik zaopatrzony być winien i mieć ja zawsze przy pracy zawieszona na narzędziu lub warsztacie, przy których pracuje.

${ }^{38}$ ZPA, cz.VI, t. II, s. 347.

39 Art. 499 instr. z 1859 r. - Pieniadze tak te, które aresztant przynióst ze soba, jako i pochodzace z zarobku w fabryce maja być odsyłane do Kas oszczędnościowych na procent. Że zaś kwoty takowe sa po większości zbyt drobne, a tem samem procent od nich nie może odpowiedniej korzyści przynosić , przeto stawia się, iż do Kas oszczędności na raz pierwszy nie może być wniesiona mniejsza kwota jak rsr $3 i$ w takim razie, jeżeli aresztantowi nie mniej jak przynajmniej rok pozostaje do wysiedzenia.

${ }^{40}$ Art. 502 instr. z 1859 r. - Przestępcy ostatecznie na karę główna skazani, jako pozbawieni wszelkich praw, a tem samem i majątkowych, nie moga otrzymywać pieniędzy, jakieby im im z zarobku w fabryce przypadty; takowe wszakże do zapadnięcia na nich ostatecznego wyroku postanawiającego rzeczoną karę, należy wykazywać w ksiązeczkach zarobkowych, bez wnoszenia ich do kas oszczędności.

${ }^{41}$ ZPA, cz.VI, t. II, s. 349. 


\section{RODZAJE WYKONYWANYCH PRAC I ORGANIZACJA PRACY}

Najstarszą formą pracy więźniów były roboty publiczne, które miały charakter hańbiący. Początkowo więźniów zatrudniano zazwyczaj np. przy budowie dróg (w Warszawie przy budowie bulwaru nad Wisłą i drogi Jerozolimskiej²), wyrębie drzewa ${ }^{43}$, budowie klasztorów ${ }^{44}$.

Niewiele wiadomo o zasadach organizacji pracy w więzieniach, jak ona przebiegała, w jakim wymiarze czasu się odbywała, choć pewne regulacje można wskazać.

Na posiedzeniu w dniu 8 października 1817 r. Rada Administracyjna zaleciła, aby Komisja Rządowa Sprawiedliwości, iz tam gdzie wypada potrzebne wyda rozkazy, iżby więźniów około dróg lub innych robót publicznych pracujący wolnymi byli od chłosty a to $w$ celu najprzód, iżby roboty przez egzekucję kar cielesnych przerywanymi nie byty, powtóre, iżby te cielesne kary pracujacym więźniom nie nadwyrężaty sit, których do uskutecznienia robót potrzebują ${ }^{45}$.

Jak pisze Niemcewicz, powszechną praktyką wśród więźniów pracujących przy robotach publicznych było żebranie, a następnie przepijanie zebranych datków w pobliskich sklepach. Jak podaje M. Senkowska, dozorcy więzienni uważali to za rzecz naturalną i nie sprzeciwiali się co pokazuje jedynie, że w tym czasie trudno było jeszcze wskazywać pracę jako element zmierzający do poprawy sprawcy ${ }^{46}$. Dlatego też Komisja Rządowa Spraw Wewnętrznych i Duchownych zakazała przyjmowania przez skazanych jakiejkolwiek jałomużny. W piśmie komisji z 19 grudnia 1819 r. skierowanym do komisji wojewódzkich czytamy: ze Skarbu publicznego dostarczane fundusze na żywność, odzież etc. I tym sposobem załatwiane maja wszelkie potrzeby, wzbroniona więc być powinna więźniom do robót publicznych użytym proszenie od przechodzacych jałomużny, czego pilnować i przestrzegać mają dozorcy więźniów i intendenci więzień pod odpowiedzialnością ${ }^{47}$.

${ }^{42}$ M. Senkowska, Kara więzienia ..., s. 132.

${ }_{43}$ Protokół Posiedzenia Rady Administracyjnej z 18 II 1823 r. - Radca Stanu przedstawiwszy wymieniony przez Komisję Województwa Mazowieckiego wniosek czyliby Władzom Rządowym i Instytutom Publicznym w stolicy tuteyszey istniejącym, które w myśl postanowienia Księcia Namiestnika z daty 21 sierpnia 1819. drzewo na opat lokalów swoich potrzebne w składach rządowych podtug ceny ustanowioney kupować sq obowiązane poleconem być mogło, ażeby do rżnięcia i tupienia takowego drzewa, używali więźniów za pewna opłata do kasy więzienney uiszczać się majaca.

${ }^{44}$ AGAD, Protokół posiedzenia Rady Administracyjnej z 5 IV 1819 r. - względem potrzeby użycia więźniów w twierdzy w Zamościu osadzonych do wniesienia klasztoru... Rada Administracyjna wyraża na to zgodę i zobowiazuje Komisję Rzadowa Spraw Wewnętrznych do wydania odpowiednich rozporzadzeń, ma to odbyć się za opłata.

${ }^{45}$ AGAD, Protokół posiedzenia Rady Administracyjnej s 8 X 1817 r.

${ }^{46}$ M. Senkowska, Kara więzienia ..., s. 134.

${ }^{47}$ AGAD, Komisja Województwa Mazowieckiego, sygn. 10040. 
Na koniec komisja rządowa dla zapewnienia bezpieczeństwa i zapobieżenia ewentualnym ucieczkom zakazała więźniom pracującym na zewnątrz z sklepów lub gospód korzystania z nich: na koniec, gdy z zapewnienie bezpieczeństwa więźniów wymaga zachowania $w$ tym względzie potrzebnych ostrożności zarządzi przeto Komisja Wojewódzka, aby nie pozwalano więźniom osądzonym lub w inkwizycji będacym pod żadnym pozorem wstepować w przechodzie do szynków i sklepików, gdzie łatwo nabyć moga narzędzia stużyć majacych do ułatwienia ucieczki lub popetnienia innych nieprzyzwoitości ${ }^{48}$.

W zakresie organizacji pracy niewiele wniosła instrukcja więzienna z 1823 r. Potwierdzając dotychczasową zasadę w art. 42 stanowiła, iż więźniowie na roboty wysyłani, powinni zawsze znajdować się pod dozorem stróża, do dziesięciu więźniów jeden stróż dodanym być ma. W każdym razie wysłania więźniów do robót publicznych, za obręb więzienia, należy zapewnić dostateczna straż dla zabezpieczenia się od gwałtownego wybicia się i ucieczki więźniów ${ }^{49}$. Art. 50 natomiast, co ważne, precyzował, że o skierowaniu więźniów do robót zewnętrznych decydował sąd wydający wyrok w danej sprawie ${ }^{50}$.

Od lat trzydziestych XIX w. organy administracji rządowej realizując postulaty penitencjarne resocjalizacji przez pracę zaczęły stopniowo zmieniać strukturę zatrudniania więźniów przenosząc punkt ciężkości z robót publicznych - mających charakter hańbiący i postrzeganych przez ówczesnych jako demoralizujące - na prace w fabrykach i warsztatach więziennych. Dlatego najprawdopodobniej w kolejnych latach nie wydawano już aktów dotyczących organizacji pracy przy robotach publicznych. Jedyne pozostałe akty prawne dotyczyły zmian w zakresie kręgu osób kierowanych do tego rodzaju prac.

Ostatecznie instrukcja więzienna z 1859 r. zakazała kierowania więźniów do robót publicznych (prócz skazanych na karę roty aresztanckiej) stanowiąc w art. 482: raz na zawsze zabrania się używać więźniów do wszelkich robót, bądź za opłata, badź bezplatnie, na czyjąkolwiek korzyść lub potrzebe publiczna ${ }^{51}$.

W pierwszych dziesięcioleciach XIX w. więźniowie mogli być także kierowani na roboty na rzecz podmiotów prywatnych. Nie było żadnych szczególnych przepisów regulujących taką formę pracy. Wydaje się, iż w tym zakresie miały zastosowanie regulacje dotyczące robót publicznych, w szczególności przepisy instrukcji więziennej z 1823 r. o obowiązku zapewnienia więźniom pracującym na zewnątrz odpowiedniego nadzoru ze strony służb więziennych.

\footnotetext{
${ }^{48}$ AGAD, Komisja Województwa Mazowieckiego, sygn. 10040.

${ }^{49}$ ZPA, cz. VI, t. I, s. 349.

50 Ibidem, s. 353.

51 ZPA, cz.VI, t. II, s. 305.
} 
Trudno powiedzieć na jaką skalę więźniowie byli kierowani do prac na rzecz podmiotów prywatnych, w dostępnych materiałach źródłowych brak informacji na ten temat. Niemniej organy administracji rządowej uważały, że tego rodzaju posługi są źródłem wielu nadużyć, ułatwiają utrzymywanie kontaktów z innymi przestępcami i stanowią niezamierzone przez ustawodawcę złagodzenie kary pozbawienia wolności. Dlatego też Komisja Rządowa Spraw Wewnętrznych, Duchownych i Oświecenia Publicznego rozporządzeniem z 8/20 listopada 1835 zakazała tego rodzaju robót ${ }^{52}$.

Na mocy postanowienia Namiestnika z 29 lipca/10 sierpnia 1832 r. podstawą pracy więźniów miały być odtąd warsztaty i fabryki więzienne. Celem tych działań, jak stanowiła Komisja Rządowa Spraw Wewnętrznych, Duchownych i Oświecenia Publicznego w instrukcji z 30 lipca 1833 r. miało być dostarczyć przez użytecznego zatrudnienia więźniom i usposobić ich przez czas trwania kary do przemystowych dóbr, po wtóre zaopatrzyć więzienia, a następnie szpitale w wyroby wetniane, lniane i konopne do codziennego ich użycia ${ }^{53}$. I tak ostatecznie komisja rządowa na mocy powyższego aktu postanowiła utworzyć w większych więzieniach karnych przędzalnie i warsztaty tkackie. Takich fabryk powstało sześć: fabryka sukna szarego grubego więziennego w Sandomierzu z pomocniczymi przędzalniami wełny w Janowie, Kielcach i Radomiu, fabryka kołder wełnianych w Pyzdrach z pomocniczą przędzalnią wełny w Kaliszu, fabryka płótna w Lublinie z pomocniczymi przędzalniami w Łukowie i Białej, fabryka płótna w Płocku z przędzalnią w Pułtusku, fabryka płótna w Łomży z przędzalnią w Kalwarii, fabryka cieńszych gatunków płótna w Łęczycy.

Jednak nie od razu fabryki te zostały zorganizowane. Na przykład fabryka sukna w Sandomierzu powstała najprawdopodobniej około 1838 r. (choć zachowane akta pochodzą dopiero od 1849), zaś pomocnicza do niej przędzalnia w Kielcach dopiero w 1849 r. lub 1850 r. Z 1849 r. pochodzi pismo Rządu Gubernialnego Radomskiego skierowane do nadzorcy więzienia w Kielcach, w którym władze wojewódzkie uprzedzają nadzorcę, iż w przedmiocie przedstawienia projektu co do urządzenia fabryk więziennych, dotychczas zadość nie uczynit, przeto Rzad Gubernialny ostrzega, iż $w$ razie nie zalatwienia powolanego polecenia $w$ przeciagu dni 3ch konieczne karnie będzie ${ }^{54}$.

Interesujące jest pismo z 1863 r. nadzorcy więzienia radomskiego do Rządu Gubernialnego Radomskiego, w którym urzędnik pisze: mam honor donieść, że z powodu znacznie zwiększonej ludności w tutejszym więzieniu, która już do 108 głów doszła nie ma zupetnie miejsca na rozpoczęcie fabryki przędzalni wetny cho-

\footnotetext{
52 ZPA, cz. VI, t. III, s. 367-369.

53 Ibidem, s. 331.

54 AP w Radomiu, zespół nr 1 Rząd Gubernialny Radomski, sygn. 10689.
} 
ciażby nawet $w$ bardzo małym zakresie ${ }^{55}$. Jak wynika z wcześniejszych dokumentów przędzalnia w więzieniu w Radomiu funkcjonowała przynajmniej od 1850 r., a więc może chodziło tutaj o jakiś dodatkowy, kolejny, zakład.

W 1848 r. Komisja Rządowa Spraw Wewnętrznych i Duchownych poleciła utworzenie przędzalni w więzieniu piotrkowskim ${ }^{56}$. Jak poleciła komisja rządowa, narzędzia niezbędne do rozpoczęcia jej działalności miały zostać sprowadzone z więzienia w Sieradzu. Jednakże już w 1849 r. z powodu braku funduszy wstrzymano jakiekolwiek prace budowlane. Ostatecznie Rząd Gubernialny Warszawski w piśmie z sierpnia 1850 r. stwierdził, iż Komisja Rządowa Spraw Wewnętrznych i Duchownych projekt wystawienia w obrębie gmachu więzienia w Piotrkowie budowli na urządzenie przędzalni odtożyla do czasu, który sama oznaczy, przędzenie zaś lnu w zbyt szczupłych kaźniach, obok ciagłego nieporzadku, pod względem dozoru kontroli bytoby zbyt utrudzającym dla Nadzorcy ${ }^{57}$. Dlatego też komisja rządowa do czasu urządzenia oddzielnych pomieszczeń fabrycznych nakazała nadzorcy odesłać z powrotem do więzienia sieradzkiego przysłane materiały i narzędzia ${ }^{58}$.

Organizacją tych jednostek zająć się miał tzw. inspektor fabryk. Urząd ten powołano na mocy decyzji Komisji Rządowej Spraw Wewnętrznych, Duchownych i Oświecenia Publicznego z 30 lipca 1833 r.: w miarę powziętych wiadomości o zaprowadzeniu fabryk, będzie mógt Inspektor, za poprzednim przełożeniem potrzeby i zezwolenia Komisji Rzadowej, udać się na miejsce, celem urządzenia tego wszystkiego, co się techniczności, porzadku postępowania i rachunkowości fabrycznej dotyczy ${ }^{59}$. Do jego zadań należało sprawdzenie kwalifikacji zatrudnionych majstrów, czy do prac fabrycznych zostali zaangażowani właściwi więźniowie (z uwagi na rodzaj ponoszonej kary, a także siłę fizyczną i umiejętności) oraz napisanie szczegółowej instrukcji. Nadto inspektorowi przydzielono funkcje nadzorcze: przy zwiedzaniu i dozorowaniu fabryk więziennych zbierać będzie Inspektor wiadomości, za zasady do dalszej kontroli stużý majace, a mianowicie: o skuteczności pracy więźniów do robót fabrycznych użytych, o stratach przy przysposabianiu materiałów ponoszonych, o koszcie utrzymania narzędzi i dostarczania materiatów pomocniczych, o ilości wyrobów z danej ilości materiałów dostarczonych ${ }^{60}$. Z przeprowadzonych kontroli inspektor składał raport Komisji Rządowej Spraw Wewnętrznych, Duchownych i oświecenia Publicznego, w któ-

\footnotetext{
55 Ibidem. 10692.

56 AP w Łodzi, zespół nr 73 Więzienie piotrkowskie, sygn. 121.

57 Ibidem. 130.

58 Ibidem.

59 ZPA, cz.VI, t. III, s. 333.

60 Ibidem, s. 335.
} 
rym miał obowiązek umieszczać, obok ogólnych spostrzeżeń o stanie fabryk więziennych, propozycje działań mogących polepszyć i udoskonalić ich pracę ${ }^{61}$.

Skutkiem zaprowadzenia fabryk więziennych była konieczność uzupełnienia dotychczasowej instrukcji więziennej z 1823 r. Dlatego też w dniu 16 maja 1833 r. wydano Urządzenie tymczasowe porządku i karności więźniów dla więzień, w których fabryki sq zaprowadzone ${ }^{62}$. Jak sama nazwa wskazuje, akt ten miał mieć charakter tymczasowy i obowiązywać do chwili przeprowadzenia ogólnej reformy więziennictwa. Jednak zapowiadana reforma nie została szybko przeprowadzona, a nowe przepisy uchwalono dopiero w $1859 \mathrm{r}$.

W myśl przepisów z 16 maja 1833 r. praca trwała 12 godzin dziennie, począwszy od siódmej rano latem, zimą zaś od ósmej. Więźniowie byli zwolnieni $\mathrm{z}$ tego obowiązku jedynie w niedziele i święta (art. 38) ${ }^{63}$. Podczas pracy nie wolno im było rozmawiać: podczas roboty $w$ fabryce, nie wolno jest mówić ani stowa do nikogo, wyjąwszy gdyby więzień przez zwierzchnika lub dozorcę robót byt zapytywany $(\text { art.17 })^{64}$. Co istotne, instrukcja ta przejawiała pewne elementy penitencjarne, na przykład art. 35 nakładał na majstra kierującego fabryką jako nauczyciela rzemiosła zachowania pełnej gorliwości w wykonywaniu swoich obowiązków ${ }^{65}$.

Co ważne, jak stanowił art. 10 Urządzenia tymczasowego: gdyby zachodzita konieczna potrzeba jakich robót publicznych starać się należy nie odrywać od nich więźniów, robotami fabrycznymi zajętych, a mianowicie też więźniów poprawczych. $W$ żadnym przypadku sam Nadzorca z swojego natchnienia żadnego więźnia do robót publicznych posyłać nie może. Do tego potrzeba upoważnienia na piśmie od Kommissyi Wojewódzkiej, wprost lub za pośrednictwem Kommisarza Obwodu uzyskanego, w którym wyrażona być ma nagła potrzeba takiego użycia więźniów ${ }^{66}$.

Instrukcja więzienna z 1859 r. zasadniczo utrzymywała w mocy wcześniejsze regulacje dotyczące organizacji pracy w fabrykach więziennych. Więźniowie mieli pracować codziennie, z wyjątkiem niedziel i świąt, choć dopuszczano pracę w wolne dni, jeżeli wymagał tego proces produkcji. Praca trwała cały dzień, z przerwami jedynie na śniadanie, obiad oraz spacer, tylko w soboty kończyła się o dwunastej. Podobnie jak w poprzednich latach, skazani przyporządkowani do zajęć w fabrykach i warsztatach nie mogli być od nich odrywani i kierowani do innych zajęćc ${ }^{67}$.

61 Ibidem.

62 Ibidem, s. 295-299.

63 Ibidem, s. 325.

64 Ibidem, s. 315.

65 Ibidem, s. 325.

66 Ibidem, s. 311.

${ }^{67}$ Art. 479 instr. z 1859 r. - Więzień do fabryki przeznaczony, nie może być bez ważnych powodów od niej oderwany i do zajęć innych obracany. 
Jak wynika z materiału źródłowego, więźniowie nie zawsze mieli zapewnioną pracę. Na przykład z powodu braku rąk do pracy w więzieniu sandomierskim, w bezczynności pozostawali osadzeni w więzieniu kieleckim i radomskim. Zwróciła na to uwagę Komisja Rządowa Spraw Wewnętrznych i Duchownych w piśmie z 1/13 sierpnia 1865 r. skierowanym do Rządu Gubernialnego Radomskiego, nakazując mu podjęcie odpowiednich działań w celu zapewnienia prawidłowej pracy fabryki więzienia sandomierskiego: aby przedsięwzięta odpowiednie środki do zaprowadzenia należytego biegu fabryki sandomierskiej ${ }^{68}$.

Jak pisze M. Senkowska, stan sanitarny w warsztatach więziennych od samego początku był zły. Pozbawienie więźniów ruchu i świeżego powietrza spowodowało, iż od czasu utworzenia fabryk więziennych wzrosła liczba chorych. Dlatego też od 1843 r. zaczęto lepiej żywić więźniów pracujących, dostarczając im dwa razy dziennie ciepły posiłek ${ }^{69}$. Jednak w kolejnych latach stan zdrowia więźniów nie uległ istotnej poprawie, mimo zapewnienia im zdrowego pożywienia, stałych spacerów i opieki lekarskiej. Jak wykazała kontrola przeprowadzona przez Głównego Inspektora służby zdrowia w 1851 r., przyczyną chorób osób pracujących w warsztatach więziennych nie były złe warunki życia, lecz proces produkcji sukna $^{70}$. Dlatego też Komisja Rządowa Spraw Wewnętrznych i Duchownych w rozporządzeniu z 27 maja/8 czerwca 1852 r. nakazała zorganizowanie suszarni sukna w oddzieleniu od pomieszczeń więziennych ${ }^{71}$.

Art. 480 instr. z 1859 r. - W dnie niedzielne i świateczne więźnie nie moga być używani do żadnych robót, wyjąwszy takich jedynie zajęć, które z koniecznej codziennej potrzeby wynikają. O ile możność pozwoli, powinny być więźniom $w$ dnie takowe udzielane odpowiednie nauki, zmierzajace ku moralnej ich poprawie i wybierane do tego ksiażki czytane na głos przez więźni umiejących czytać, pod nadzorem straży.

Art. 484 instr. z 1859 r. - Aresztanci zajmować się maja pracami fabrycznymi całodziennie, jak wskazano w artykułach 25 i 30-m, za wyłaczeniem przestanków na śniadanie, obiad i przechadzki. Po skończonej robocie, pora letnia, udzielane będzie dobrze sprawującym się więźniom pozwolenie przechadzania się po dziedzińcu do godziny 8-ej lub krócej, gdy zmrok wprzódy zapadnie; o 8-ej wszyscy musza być w właściwych sobie izbach sypialnych, które natychmiast pozamykane być mają.

Art. 485 instr. z 1859 r. - W sobotę kończa się roboty fabryczne w poludnie, a reszta czasu ma być poświęcona czyszczeniu lokalu fabrycznego; więźnie zaś do tego nieużyci maja trzepać sienniki $i$ kołdry swoje na dziedzińcu koleja izb sypialnych tak, aby jedni drugim nie przeszkadzali.

${ }_{68}$ AP w Radomiu, zespół nr 1 Rząd Gubernialny Radomski, sygn. 10692.

${ }^{69}$ M. Senkowska, Kara więzienia ..., s. 139-140.

${ }^{70}$ W rozporządzeniu Komisji Spraw Wewnętrznych i Duchownych z 27 maja/8 czerwca 1852 r. czytamy, że przyczyna chorób polega w samej fabrykacji sukna, mianowicie w szlichtowaniu czyli sterkowaniu sukna, a raczej przędzy na osnowe, do czego się używa maka i klej; albowiem klej do szlichty gotuje się w więzieniu z rozmaitych resztek zwierzęcych od garbarzy zakupywanych $i$ przewapnionych, $w$ szlichcie tak przyrzadzonej moczona przędza rozwieszana jest po salach, nie tylko wiec gotowanie kleju, ale sama szlichta i suszenie przędzy wydaje odór nieznośny, szkodliwe dla więźni.

${ }^{71}$ ZPA, cz.VI, t. III, s. 529. 
Oprócz robót fabrycznych więźniowie wykonywali także inne prace na terenie jednostek penitencjarnych, zapewne miały one charakter głównie porządkowy czy administracyjny (choć w dostępnym materiale źródłowym brak jakichkolwiek danych na ten temat).

W tym zakresie próżno szukać też odrębnych przepisów administracyjnych regulujących organizację tych robót. Możemy przypuszczać, iż w tym zakresie stosowano reguły zbliżone do tych, które obowiązywały więźniów pracujących w warsztatach.

W zakresie pewnej organizacji prac wewnętrznych możemy wskazać rozporządzenie Komisji Rządowej Spraw Wewnętrznych Duchownych i Oświecenia Publicznego z 8/20 listopada 1835 r., w którym wskazano, że do posług prywatnych wewnątrz zakładów karnych można wykorzystywać tylko osoby, których nie przydzielono do prac fabrycznych ${ }^{72}$.

Ta zasada została utrzymana $\mathrm{w}$ instrukcji więziennej z 1859 r., która dodatkowo zabraniała używania osadzonych do pisania w kancelariach więziennych ${ }^{73}$.

\section{KATEGORIE WIĘŹNIÓW KIEROWANYCH DO PRACY}

Obowiązujący od 1818 r. Kodeks Karzący (dalej: KK) obowiązek pracy przewidywał w przypadku skazania na karę więzienia warownego, więzienia ciężkiego i więzienia poprawczego, a także aresztu publicznego ${ }^{74}$.

Art. $31 \mathrm{KK}$ stanowił, że skazani na więzienie warowne użyci być powinni do prac najprzykrzejszych zewnętrznych lub wewnętrznych, ile ich stan zdrowia $i$ sit dozwoli ${ }^{75}$, a podczas pracy mieli być przykuwani do taczek ${ }^{76}$.

Skazani na więzienie ciężkie użyci być maja do prac zewnętrznych lub wewnętrznych, ile ich stan zdrowia $i$ sit dozwoli (art. $32 \mathrm{KK})^{77}$. A zatem w tym przypadku nie musiały to być prace najprzykrzejsze, a więźniowie nie byli przykuwani do taczek.

Podobnie KK ujmował pracę więźniów poprawczych: używani będa do prac wewnętrznych $i$ zewnętrznych, ile stan ich sit $i$ zdrowia dozwoli ${ }^{78}$.

W przypadku natomiast skazania na karę aresztu publicznego, użyci być maja do robót lub zatrudnieni tylko wewnętrznych, których wybór zostawiony tym jest,

72 Ibidem, s. 367-369.

73 ZPA, cz. VI, t. II, s. 305.

${ }^{74}$ Jedynie kara aresztu policyjnego uregulowana w art. 472 KK nie wiązała się z obowiązkiem pracy.

${ }^{75}$ Kodeks Karzący Królestwa Polskiego, b m i d w, s.7.

76 Ibidem.

77 Ibidem.

78 Ibidem, s. 49. 
co się własnym utrzymują kosztem; dla tych zaś którzy kosztem skarbu sa utrzymywani, w miare zdrowia $i$ sil fizycznych roboty wyznaczone będa ${ }^{79}$.

Widać wyraźną różnicę między trzema pierwszymi kategoriami więźniów a więźniami skazanymi na areszt publiczny. Ci ostatni mogli być kierowani tylko do robót wewnątrz więzienia. Wynikało to, jak pisze J. Śliwowski, z odmienności aresztu publicznego jako typu kary, ponieważ dla uprzywilejowanych była to kara niehańbiąca, a za takie uchodziły roboty zewnętrzne ${ }^{80}$.

Obowiązujący od 1848 r. Kodeks Kar Głównych i Poprawczych (dalej: KKGiP) również nakładał obowiązek pracy na osoby skazane na karę pozbawienia wolności. Ta dodatkowa sankcja związana była $\mathrm{z}$ karą osadzenia $\mathrm{w}$ rocie aresztanckiej, a także zamknięcia $\mathrm{w}$ domu roboczym i domu poprawy.

Art. $48 \mathrm{KKGiP}^{81}$ przewidywał, iż skazani na pobyt $\mathrm{w}$ rotach aresztanckich będą mogli być używani zarówno do prac zewnętrznych, jak wewnętrznych.

Natomiast art. 57 KKGiP stanowił, iż skazani na zamknięcie $w$ domach roboczych $i w$ domach poprawy używani będa jedynie do robót wewnętrznych, wskazanych $w$ urzadzenia tych domów ${ }^{82}$.

Ponadto osoby skazane na karę osadzenia w twierdzy mogły pracować, o ile wyraziły taką chęć: skazani na osadzenie w twierdzy trzymani będa w urządzonych na ten cel wewnatrz twierdz $w$ budowlach i moga stosownie do wtasnego życzenia , możliwymi w miejscu ich osadzenia robotami (art. $56 \mathrm{KKGiP})^{83}$.

Widzimy, że kodeks karny z 1847 r. istotnie ograniczał krąg osób zobowiązanych do prac zewnętrznych. Do takich prac mieli być używani tylko skazani na umieszczenie w rocie aresztanckiej. Przepisy te niewątpliwie wpisywały się w ogólny trend zmiany struktury organizacyjnej zatrudniania skazanych z robót publicznych (które miały charakter hańbiący) na prace w fabrykach i warsztatach więziennych, co z kolei było związane z działaniami penitencjarnymi państwa.

Wskazane przepisy kodeksowe były szczegółowo precyzowane w drodze regulacji wydawanych przez organy administracji rządowej.

29 lipca/10 sierpnia 1832 r. Rady Administracyjnej wydała postanowienie, że do robót publicznych są przeznaczeni przede wszystkim zbrodniarze skazani na więzienie ciężkie ${ }^{84}$.

${ }^{79}$ Kodeks Karzący Królestwa Polskiego, b m i d w, s.49.

${ }^{80}$ J. Śliwowski, Kodeks Karzący Królestwa Polskiego, Warszawa 1958, s. 13.

${ }^{81}$ Art. $48 \mathrm{KKGiP}$ - skazani na oddanie do poprawczych aresztanckich rot będa użyci do wewnętrznych i zewnętrznych robót $w$ twierdzach. Jeżeli sa skazani, oprócz robót, na chłostę, odbiora ja wobec innych więźni, wewnątrz twierdzy w przerwach dwutygodniowych, po czterdzieści rózg na raz jeden.

82 Kodeks Kar Głównych i Poprawczych, Warszawa 1847, s. 37.

83 Ibidem. Od pracy natomiast wyłączeni byli skazani na osadzenie w wieży i areszt na czas krótki.

${ }^{84}$ Art. 7 post. z 29 lipca/10 sierpnia 1832 r. - Skazani na lat $10 i$ więcej ciężkiego więzienia, jako i ci, którzy za powtarzane występki i zbrodnie tę karę ponosza, choćby tylko na 5 lat skazani być mieli, będa używani do ciężkich robót publicznych $i$ wcieleni do kompanij poprawczych aresztanckich. 
Natomiast do tych prac nie mogły być kierowane osoby znajdujące się pod śledztwem, skazane na areszt publiczny, zaś więźniowie poprawczy tylko w razie niezbędnej potrzeby ${ }^{85}$.

Jednak w kolejnych latach więźniowie nadal cierpieli na bezczynność, a w przepełnionych więzieniach szerzyły się choroby. Lekarstwem na to miało być złagodzenie przepisów dotyczących kierowania osadzonych na roboty publiczne. W piśmie Komisji Rządowej Spraw Wewnętrznych do Rządu Warszawskiego z 18/30 grudnia 1845 r. czytamy: praktykowane dziś w ogólności jak wiadomo Rzadowi Gubernialnemu przeludnienie więzień, tudzież wzmagajace się $w$ nich choroby i brak zatrudnienia dla więzionych przy fabrykach więziennych, zwrócity uwage Komisji Rządowej Spraw Wewnętrznych na niemożność utrzymania w obecnym czasie powyższego rygoru rozporzadzenia z 8/20 listopada 1835 r. co do używania do robót publicznych samych tylko winowajców na więzienie ciężkie skazanych i tym sposobem i wskazuje potrzebe wysytania więźniów poprawczych...Z tego zatem powodu tudzież z uwagi, że podobne postępowanie zapewni dochód funduszom więziennym których brak coraz bardziej czuć się daje, nade wszystko zaś wystawienie więźniów na świeże powietrze, wywrze korzystny wptyw na ich zdrowie. Komisja Rzadowa poleca Rzadowi Gubernialnemu, aby od chwili odebrania niniejszego, do wszystkich robót rządowych lub na użytek miast, gmin albo instytutów...używat za opłata...nie tylko więźniowie karę ciężkiego więzienia cierpiacych lecz i tych, którzy na kare poprawcza sa

${ }^{85}$ Art. 3 - Więźniowie pod instrukcya będacy nie moga być przymuszani do żadnych robót; używać ich można przy warsztatach więziennych o tyle, ile właściwe Sady na to zezwola i o ile sami sobie życzyć tego będą. Inkwizyci osobno osadzeni, moga otrzymać zatrudnienie, któreby w celach swoich wykonywać mogli.

Art. 4 post. z 29 lipca/10 sierpnia 1832 r. - Więźniowie, na areszt publiczny skazani, nie moga być używani, pod żadnym pozorem, do żadnych do robót publicznych, tylko w obrębach więzienia zatrudnionymi być moga, stosownie do art. 217-go Kodeksu Karzacego.

Art. 217 Kodeksu Karzącego - Zamknięci w domu aresztu publicznego wolni będa od kajdan moga się z własnego utrzymywać majątku, żaden jednak zbytek dozwolony im nie będzie. Stug własnych i domowników wtenczas tylko do postugi używać moga, gdy sąd w miarę koniecznej potrzeby im dozwoli. Nikogo $w$ areszcie przyjmować i z nikim bez zezwolenia sqdu widzieć się i rozmawiać nie powinni. Gdyby zaś sami utrzymywać się nie byli w stanie, żywność i inne potrzeby stosownie do przepisu art. 216 zawartego dostarczane im będą. Naostatek uzyci bydć maja do robót lub zatrudnieni wewnętrznych, których wybór zostawiony tym jest, co się własnym utrzymuia kosztem; dla tych zaś którzy kosztem skarbu sq utrzymywani, w miarę zdrowia i sit fizycznych roboty wyznaczone będą.

Art. 5 post. z 29 lipca/10 sierpnia 1832 r. - Więźniowie poprawczy powinni być ciagle zajęci robotami fabrycznymi w samych więzieniach i do robót publicznych wtenczas tylko używani, jeżeli konieczna potrzeba tego wymagać będzie .

Z rozporządzenia wprowadzającego w wykonanie postanowienie Rady Administracyjnej z 29 lipca/10 sierpnia 1832 r. wynika, iż do czasu urządzenia w więzieniach fabryki i warsztatów więźniowie inkwizycyjni, jak i skazani na areszt publiczny, będą mogli tak jak dotychczas pracować przy robotach publicznych - ZPA, cz. VI. T. III, s. 301. 
skazani $^{86}$. W tym samym akcie komisja rządowa pozwoliła na używanie defraudantów do czyszczenia ulic miejskich ${ }^{87}$.

Wejście w życie w 1848 r. Kodeksu Kar Głównych i Poprawczych spowodowało konieczność ustalenia na nowo kategorii więźniów przeznaczonych do poszczególnych rodzajów robót. Na mocy rozporządzenia Komisji Rządowej Spraw Wewnętrznych i Duchownych z 4/16 lutego 1850 r. do robót zewnętrznych mogli być kierowani tylko skazani na karę roty aresztanckiej: spomiędzy kar poprawczych tylko kara rot aresztanckich (art. 48) połaczona jest z robotami wewnętrznymi i zewnętrznymi w twierdzach...Tylko skazani do rot aresztanckich moga być użyci do robót $w$ cytadeli, gdy jednakże podobne roty urzadzony sa tylko w twierdzach w Nowogieorgiewska, Zamościa i Iwanogrodzie ...przeto obecnie może być tylko dozwolone czasowe posytanie do cytadeli takich przestępców, którzy sa skazani na dom roboczy, byleby tylko poza obręb cytadeli do robót używani nie byli ${ }^{88}$.

Te zasady utrzymano w instrukcji więziennej z $1859 \mathrm{r}^{89}$.

Przepisy administracyjne precyzowały także kwestię zatrudniania osadzonych przy robotach wewnętrznych.

W myśl postanowienia Namiestnika z 29 lipca/10 sierpnia 1832 r. w organizowanych wówczas fabrykach i warsztatach więziennych mieli pracować skazani na areszt publiczny, więźniowie poprawczy, a także osoby odbywające karę więzienia ciężkiego, o ile zostały skazane na mniej niż 10 lat i nie było dla nich pracy przy robotach publicznych ${ }^{90}$.

Jednak już Urządzenie tymczasowe porządku i karności więźniów dla więzień, w których fabryki sa zaprowadzone ${ }^{91}$ z 16 maja 1833 r. w art. 5 zakazywało pracy w fabrykach więziennych skazanym na karę aresztu publicznego ${ }^{92}$.

${ }^{86}$ AP w Łodzi, zespół nr 73 Więzienie piotrkowskie, sygn. 121.

${ }^{87}$ Ibidem.

${ }^{88}$ ZPA, cz.VI, t. III, s. 555.

89 Art. 113 inst. z 15/27 sierpnia 1859 - Więźnie na roboty $w$ cywilnych aresztanckich rotach prawomocnie skazani, powinni być odsytani do twierdz Królestwa, mianowicie: do Iwangrodu z więzień: Płockiego, Puttuskiego Kieleckiego, Chęcińskiego i Radomskiego; do Nowogeorgiewska z więzień: Warszawskim, Kaliskiego, Lęczyckiego, Brzeskiego, Sieradzkiego, Piotrkowskiego, Lomżyńskiego i Kalwaryjskiego; do Zamościa z więzień: Lubelskiego, Janowskiego, Bialskiego, Siedleckiego i Sandomierskigo. W przypadku niemożności dla braku miejsca przeniesienia więźni do której z twierdz, wedlug powyższego podziału, moga być oni odsyłani, bez względu na ten podziat, do innej z powyższych twierdz, gdzie będzie miejsce.

${ }^{90}$ ZPA, cz.VI, t. III, s. 315.

${ }^{91}$ Ibidem, s. 295-299.

92 Art.5 Urządzenia tymczasowego... z 16 maja 1833 r. - przestępcy na areszt publiczny skazani, ile możności w innem miejscu jak w więzieniach karnych mieszczeni być powinni. W razie koniecznej potrzeby przyjęcia ich do tychże więzień, należy przeznaczać im osobna izbę, tak aby żadnej styczności z resztą winowajców w więzieniu osadzonych nie mieli. Jeżeli żądają zatrudnienia, można im go dostarczać w miejscu ich pobytu, ale do fabryk używać ich nie należy. 
Powyższe regulacje wskazywały, że w fabrykach mają pracować głównie więźniowie poprawczy oraz skazani na więzienie ciężkie. Nie wolno było zatrudniać w warsztatach więźniów poprawczych skazanych na mniej niż trzy miesiące, można ich było używać tylko do posług domowych, ewentualnie w razie koniecznej potrzeby przy lżejszych pracach fabrycznych ${ }^{93}$. Co ważne, wskazano, że w razie braku miejsc więźniowie poprawczy mieli zawsze pierwszeństwo przed osobami skazanymi na więzienie ciężkie ${ }^{94}$.

Po wejściu w życie Kodeksu Kar Głównych i Poprawczych w 1848 r. Komisja Rządowa Spraw Wewnętrznych i Duchownych z 4/16 lutego 1850 r. ustalając na nowo kategorię więźniów kierowanych do prac wewnętrznych stanowiła, iż skazani na karę: zamknięcia $w$ domu roboczym lub poprawy skutkiem sa jedynie roboty wewnętrzne (art. 57). Skazani zaś na karę wieży wtenczas tylko, jeśli nie sa w stanie sami się utrzymać, zajęci być moga robota wewnętrzna i to taka jaka sobie wybiora, za która maja być płatni...Stad wypływa, że używanie do postug więziennych domowych i robót zewnętrznych, około czyszczenia placów i ulic, otaczających domy więzienne, aresztantów na karę wieży podtug nowego Kodeksu osądzonych, która choćby w najwyższym stopniu wymierzana, nie pociaga za soba żadnych skutków hańbiacych, dopuszczanym być nie powinno i tylko więźniowie na dom roboczy skazani moga być do rzeczonych prac używani...Tylko skazani do rot aresztanckich moga być użyci do robót $w$ cytadeli, gdy jednakże podobne roty urzadzony sa tylko $w$ twierdzach $w$ Nowogieorgiewska, Zamościa i Iwanogrodzie ... przeto obecnie może być tylko dozwolone czasowe posytanie do cytadeli takich przestępców, którzy sa skazani na dom roboczy, byleby tylko poza obręb cytadeli do robót używani nie byli ${ }^{95}$.

Nowa instrukcja więzienna z 1859 r. utrzymywała dotychczasowe zasady, wskazując dodatkowo jedynie defraudantów jako osoby, które mogą być kierowane do prac fabrycznych ${ }^{96}$. Obowiązani do prac wewnętrznych byli skazani na karę roty aresztanckiej, zamknięcia $\mathrm{w}$ domu roboczym i domu poprawy. Natomiast skazani na karę wieży lub osadzenie w twierdzi mieli obowiązek pracy (i to takiej, którą sami sobie wybrali), gdy nie mogli się samodzielnie utrzymaćc ${ }^{97}$.

93 ZPA, cz.VI, t. III, s. 309-310.

94 Ibidem, s. 311.

95 Ibidem, s. 555.

${ }^{96}$ Art. 477 KKGiP - W więzieniach, gdzie istnieja fabryki wyrobów płóciennych, wetnianych $i$ konopnych oraz pomocnicze do nich przędzalnie, aresztanci osadzeni, których prawo karne od robót nie wyłazca i defraudanci, jak również ci z więźni pod badaniem będacych, którzyby tego żądali $i$ nie będzie ze strony Sąu zachodzić przeszkoda - używani będa do robót w rzeczonych fabrykach i przędzalniach.

${ }^{97}$ Art. 56 KKGiP - Skazani na osadzenie $w$ twierdzy trzymani będa w urzadzonych na ten cel wewnatrz twierdz budowlanych i moga, stosownie do własnego życzenia, zajmować się możliwemi w miejscu ich osadzenia robotami. 
Jednak, jak wynika $\mathrm{z}$ dostępnego materiału archiwalnego, w fabrykach więziennych raczej brakowało rąk do pracy. Tak np. już w 1850 r. naczelnik więzienia sandomierskiego w piśmie skierowanym Rządu Gubernialnego Radomskiego podaje, iż mała ilość wyrobu sukna ... pochodzi z ogólnej ilości więźniów do fabryki potrzebnej i niedostatku nadesłanych aresztantów, których liczba zmniejszyła się przez odestanie kilku do twierdzy w Zamościu ${ }^{98}$.

W kolejnych latach nie było chyba lepiej. Aby fabryka należycie pracowała, próbowano te braki uzupełnić. Np. w 1864 r. Komisja Rządowa Spraw Wewnętrznych poleciła na wniosek Rządu Gubernialnego Radomskiego sprowadzić do więzienia sandomierskiego 50 więźniów z jednostek penitencjarnych guberni lubelskiej. Jednak Rząd Gubernialny Lubelski w odpowiedzi wskazał, iż z więzień lubelskich do przeprowadzenia kwalifikuje się tylko 10 (pozostali mogący pracować w fabrykach byli zatrudnieni w fabryce płótna w więzieniu lubelskim) ${ }^{99}$. W takim stanie rzeczy komisja rządowa oświadczając, że pomóc nie może z powodu zmniejszającej się liczby więźniów, stwierdziła: nie pozostaje zatem obecnie Rzadowi Gubernialnemu (radomskiemu) jak dopilnować, żeby produkcja sukna w fabryce sandomierskiej odpowiednia była do ilości aresztantów kwalifikujacych się do robót ${ }^{100}$.

W następnym roku nadzorca więzienia sandomierskiego podejmował dalsze próby sprowadzenia z innych części Królestwa Polskiego więźniów, co było jednak bardzo trudne. Tak np. w piśmie nadzorcy do Gubernatora Cywilnego Guberni Radomskiej z 12/24 października 1865 r. czytamy: reskryptem Rządu Gubernialnego...powiadomiony został nadzorca więzienia, że z więzienia kieleckiego miato być nadesłanych 20 więźniów, wskutek czego Nadzorca kielecki ledwo 7 aresztantów osadzonych na Dom Roboczy, z których 3 już wiekowych $i$ zupetnie do żadnej roboty niezdatnych, a jeden z nich zostaje jako staby $w$ lazarecie, $z 7$ więc nadestanych liczyć można tylko 4 do lekkiej pracy... z tego tytulu Nadzorca więzienia donosząc o tym Jaśnie Wielmożnemu Panu ma honor prosić o rozkazanie nadestania zadysponowanej ilości więź-

Art. $57 \mathrm{KKGiP}$ - Skazani na zamknięcie $w$ domach roboczych $i$ w domu poprawy używani będa jedynie do robót wewnętrznych, wskazanych w urządzeniach tych domów.

Art. $59 \mathrm{KKGiP}$ - Skazani na osadzenie w wieży moga, stosownie do własnego życzenia, zajmować się dozwolonemi w miejscu ich osadzenia robotami; ci wszakże, którzy nie sa w stanie utrzymać się własnym kosztem, obowiazani sa wybrać do zajęcia się jednę z robót w tem miejscu zaprowadzonych. Za roboty tego rodzaju wyznacza się, podlug osobnych urzadzeń, stosowna płaca, lecz w każdym przypadku, należne osadzonym, za robotę, pieniężne wynagrodzenie, nie pierwej wydane im zostanie, jak przy wypuszczeniu ich na wolność.

${ }_{98}$ AP w Radomiu, zespół nr 1 Rząd Gubernialny Radomski, sygn. 10689.

${ }^{99}$ Ibidem, 10692.

${ }^{100}$ Ibidem. 
niów głów 20, lecz zdrowych i do pracy fabrycznej zdolnych ${ }^{101}$. W odpowiedzi kierowanej do Rządu Gubernialnego Radomskiego, Naczelnik Powiatu Kieleckiego stwierdził, że nie ma odpowiedniej liczby mężczyzn zdolnych do pracy w fabryce, ale może przysłać w to miejsce kobiety: mam zaszczyt donieść, iż tylko siedmiu więźniów z Kielc...do Sandomierza przesłano, gdyż więcej z tej kategorii mężczyzn nie byto - na zasadzie jednak opinii nadzorcy karnego wnoszę, aby brak robotników przy fabryce sandomierskiej zastapić kobieta$m i^{102}$. Ostatecznie z więzienia kieleckiego do sandomierskiego przesłano piętnastu mężczyzn i pięć kobiet ${ }^{103}$.

Odrębnym zagadnieniem jest kwestia zatrudniania osób tymczasowo aresztowanych.

Mówi o tym po raz pierwszy instrukcja więzienna z 1823 r. W myśl art. 51 osoby, względem których nie zapadł jeszcze wyrok, mogły być kierowane tylko do robót wewnątrz więzienia i tylko za zgodą właściwego sądu ${ }^{104}$.

Postanowienie Namiestnika z 29 lipca/10 sierpnia 1832 r. pozwalało na pracę więźniów inkwizycyjnych w fabrykach i warsztatach więziennych, ale tyko na zasadzie dobrowolności i za zgodą sądu.

Zasady te zostały utrzymane w Urządzeniu tymczasowym porządku $i$ karności więźniów dla więzień, w których fabryki są zaprowadzone z 16 maja 1833 r., z tym dodatkowym zastrzeżeniem, że więźniów inkwizycyjnych można było zatrudniać tylko wtedy, gdy pozostawały wolne miejsca pracy ${ }^{105}$.

W zakresie pracy więźniów pod badaniem będacych nie zmieniła instrukcja więzienna z 1859 r. Nadal mogli być oni zatrudniani w fabrykach i warsztatach więziennych, jeżeli zgłosili taki wniosek, a sąd, w dyspozycji którego pozostawali, nie zgłosił sprzeciwu ${ }^{106}$.

Odrębną kwestią jest zagadnienie pracy kobiet. Początkowo przepisy nie stanowiły różnicy ze względu na płeć. Kobiety mogły być zatrudniane zarówno przy pracach zewnętrznych i wewnętrznych. Choć jak podaje M. Senkowska w począt-

101 Ibidem.

102 Ibidem.

103 Ibidem.

104 Art.51 inst. z 1823 r. - Względem używania do roboty wewnętrznej w więzieniach więźniów nieosądzonych, pod inkwizycja będących, Nadzorca obowiązanym jest uzyskać pozwolenie właściwego Sądu, to jest bez wiedzy tego Sądu żadnego więźnia pod inkwizycyą zostającego do robót nie używać.

105 ZPA, cz.VI, t. III, s. 306.

106 Art. 477 inst. z 15 VIII 1859 r. - W więzieniach, gdzie istnieją fabryki wyrobów płóciennych, wetnianych i konopnych oraz pomocnicze do nich przędzalnie, aresztanci osadzeni, których prawo karne od robót nie wyłącza i defraudanci, jak również ci z więźni pod badaniem będących, którzyby tego żądali i nie będzie ze strony Sądu zachodzić przeszkoda - używani będą do robót w rzeczonych fabrykach i przędzalniach. 
ku XIX w. większość kobiet pozostawała bez jakiegokolwiek zatrudnienia w jednostkach penitencjarnych ${ }^{107}$.

Ostatecznie Komisja Rządowa Spraw Wewnętrznych, Duchownych i Oświecenia Publicznego rozporządzeniem z 8/20 listopada 1835 r. wprowadziła bezwzględny zakaz kierowania kobiet do robót publicznych, nawet tam, gdzie nie było warsztatów więziennych ${ }^{108}$.

Niestety w zachowanym materiale archiwalnym nie odnajdujemy żadnych szczególnych informacji, jak faktycznie wyglądała kwestia zatrudniania kobiet, choć na pewno w fabrykach więziennych pracowały. Odnajdujemy na przykład informację o skierowaniu pięciu kobiet $\mathrm{z}$ więzienia kieleckiego do fabryki w więzieniu sandomierskim ${ }^{109}$.

Instrukcja więzienna z 1859 r. zakazywała zatrudniania kobiet do osobistych posług dla oficjalistów więziennych ${ }^{110}$.

\section{ZAKOŃCZENIE}

Powyższe rozważania ukazują, jak bardzo w XIX w. zmieniły się warunki pracy wykonywanej przez osoby pozbawione wolności w więzieniach Królestwa Polskiego.

Z chwilą wprowadzenia Kodeksu Karzącego administracja więzienna w żaden sposób nie była przygotowana do wypełnienia ustawowej przesłanki pracy jako elementu kary pozbawienia wolności. Zasadniczo jedynym zajęciem, jakie zapewniano skazanym, były roboty publiczne, które po pierwsze stanowiły często źródło nadużyć i jeszcze większej demoralizacji więźniów, a po drugie miały bardzo ograniczony zakres i nie wyczerpywały siły roboczej. Dopiero w połowie lat dwudziestych XIX w. centralne organy administracji rządowej, i to przede wszystkim z powodów fiskalnych, próbują zwiększyć liczbę miejsc pracy. Istotne zmiany możemy obserwować dopiero po roku 1832 wraz z organizacją fabryk i warsztatów więziennych, co istotnie zwiększyło odsetek pracujących więźniów.

Na przekształcenia $\mathrm{w}$ strukturze zatrudnienia więźniów miały też niewątpliwie wpływ rozwijająca się publicystyka penitencjarna, kładąca nacisk na funkcję

${ }^{107}$ M. Senkowska, Kara więzienia ..., s. 132.

108 ZPA, cz.VI, t. III, s. 367-369.

109 AP w Radomiu, zespół nr 1 Rząd Gubernialny Radomski, sygn. 10692.

110 Art. 483 inst. z 15 VIII 1859 r. - Również jak najmocniej zabrania się używania więźni do pisania w kancellaryi więziennej. Używanie aresztantów przez Nadzorcę więzienia lub z jego pozwolenia przez którego z oficjalistów więziennych do postug ich własnych, może mieć miejsce li tylko wewnątrz murów więziennych, do czego nie inni aresztanci jak tylko ptci męskiej i to tacy, którzy sa wolni od zajęć fabrycznych lub do nich nie kwalifikuja się, moga być wybierani. 
wychowawczą i resocjalizacyjną pracy, stąd też postulaty J.U. Niemcewicza, czy F. Skarbka odejścia od robót publicznych.

Na tle tych zmian rozwija się ustawodawstwo administracyjne, którego w chwili powstania Królestwa Polskiego zasadniczo nie było. Organy administracji rządowej wydają kolejne decyzje reagując na aktualne potrzeby. Z biegiem lat wydawane są akty administracyjne coraz bardziej szczegółowo określające zarówno organizację pracy, kategorie więźniów mogących być kierowanymi do pracy czy też inne kwestie, jak na przykład wynagrodzenie.

\section{THE ORGANIZATION OF PRISON LABOUR IN THE KINGDOM OF POLAND BETWEEN 1815 AND 1867}

\section{Summary}

The convicts' obligation to perform prison labour as an additional form of punishment beyond imprisonment appeared for the first time in the $16^{\text {th }}$ century together with the creation of houses of correction. In the $19^{\text {th }}$ century, statutory law pertaining to labour was regulated in many European penal codes. This concept was also included in the criminal legislation which was in force in the Kingdom of Poland, i.e. in the Penal Code (in force since 1818) and in the Code of Major and Correctional Punishments (since 1848). Initially, the work carried out by the prisoners in the Kingdom of Poland was primarily fiscal in nature. The purpose of the labour was for the prisoners to, at least partially, earn a living. However, the penitentiary concepts which began to emerge from the 1930s onwards also started to notice the educational and resocialization value of convict labour. At first, the prisoners were mainly engaged in public works. And later, after 1832, they were put to work in prison workshops and factories. Moreover, they performed services for the benefit of private individuals. The Penal Code obliged the prisoners to work in case of convicts placed in prisons and jails. The Code of Major and Correctional Punishments, which was in force since 1848, maintained the prison labour obligation of the convicts' sentenced to imprisonment. This additional sanction was connected with the punishment of imprisonment in detention centres and it was also connected with being detained in workhouses or in houses of correction. People sentenced to lighter punishments and those temporarily deprived of liberty were free from penal labour.

\section{ORGANISATION DU TRAVAIL PÉNITENTIAIRE AU ROYAUME DE POLOGNE DANS LES ANNÉES 1815-1867}

\section{Résumé}

L'obligation des prisonniers de travailler étant conçu en tant qu'une contrariété supplémentaire de la peine de privation de liberté est apparue au XVI ${ }^{\mathrm{e}}$ siècle avec la création des établissements correctionnels. Au XIX ${ }^{\mathrm{e}}$ siècle, cette obligation était prévue par la loi dans de nombreux codes pénaux européens. Ce concept était inclus également à la législation pénale au Royaume de Pologne, à savoir le Code punitif (en vigueur depuis 1818) et 
le Code de peines principales et correctionnelles (en vigueur depuis 1848). Au Royaume de Pologne, le travail des prisonniers avait avant tout le caractère fiscal et visait à gagner par le prisonnier au moins une partie des moyens de subsistance pour lui-même.

Les concepts pénitentiaires qui sont apparus à partir des années 1930 du XIX , ont $^{2}$ cependant commencé à trouver dans le travail des détenus des éléments éducatifs et de resocialisation. Initialement, les prisonniers étaient principalement employés au service les travaux publics, et après 1832, dans les ateliers et les établissements pénitentiaires, ils pouvaient également exercer les services au profit des personnes privées. Le Code punitif stipule l'obligation de travailler en cas de condamnation à une peine de réclusion de longue durée, de prison lourde et de prison correctionnelle, ainsi que de prison publique. Le Code de peines principales, en vigueur depuis 1848, maintenait l'obligation du travail des condamnés à l'emprisonnement. Cette sanction supplémentaire était liée à la peine d'emprisonnement dans une compagnie correctionnelle, ainsi qu'à la peine de placement sous garde dans un foyer de travail et dans un établissement correctionnel. Par contre, les personnes condamnées à des peines plus légères et temporairement privés de liberté n'étaient pas soumises aux travaux forcés. 
